\title{
Mediation Effects of Internet Addiction on Shame and Social Networking
}

\author{
Uğur Doğan, Sinem Kaya* \\ Faculty of Education, Mugla Sitki Kocman University, Turkey
}

Copyright $(2016$ by authors, all rights reserved. Authors agree that this article remains permanently open access under the terms of the Creative Commons Attribution License 4.0 International License

\begin{abstract}
A survey of 488 college students was conducted in Turkey to investigate the relationship between social network usage, shame and Internet addiction. It was hypothesized that a relationship between shame and social network usage was mediated by Internet addiction. First of all, according to simple regression analysis, it was found that shame significantly and positively predicted social network usage. A simple mediation model, which was applied with regression-based mediation analysis, showed that shame did not predict social network usage when Internet addiction was inserted in the model. Therefore, Internet addiction is a mediating variable between shame and social network usage. According to the results of mediation analysis, Internet addiction of college students is an important predictor in terms of social networking site (SNS) usage.
\end{abstract}

Keywords Shame, Internet Addiction, Social Network Usage, Mediation Analysis

\section{Introduction}

In recent decades, Internet use, particularly social networking, interactive games and online shopping, is increasing at a rapid and uncontrollable rate. This reality leads us to the problem of Internet addiction [1]. Internet addiction has negative consequences on emotional, cognitive and behavioral development [2]. Despite the positive role the Internet can play in daily life when used in moderation, over time, its users tend to communicate less and spend less time with other people. So, they often experience disconnection from their relationships with other people [3]. When shame is considered in the scope of Internet addiction, it seems to lose its significance with regard to social networking usage, because individuals suffering from Internet addiction may not place importance on their social life. Thus shame may not be that important to the daily lives of Internet-addicted individuals, because that addiction itself has diminished their usual social communications. Consequently, their position as either a sociable person or a shamed person is not very relevant within the context of social networking.

Shamed individuals can feel insecurity and low self-confidence [4]. These well-known characteristics of shame limit individuals from easily socializing with other people. Actually, social anxiety and shame have some similar characteristics. Shaw, Timpano, Tran \& Joormann [5] reported that social networking platforms may become a social sphere, providing a secure area especially for individuals who feel anxious in social contexts and diminishing the anxiety level during socialization with other people. This increased comfort may be because online platforms can wipe away insecurity and unconfident feelings with the alternative of being able to contact other people without any face-to-face communication. Previous literature is consistent with the idea, noting that individuals with higher levels of social anxiety report a comparatively greater feeling of comfort when socializing online than when socializing face-to-face $[6,7]$. It can be deduced from this information that shame may play an important role in online socialization.

Various studies have investigated the affecting factors of SNS usage like social identity [8], social appearance anxiety [9], loneliness [6, 9, 10], low self-esteem [11, 12], social anxiety [5, 10], well-being [13, 14], life satisfaction [13, 15], happiness [13], depression [16], self-concealment [9], psychopathological profiles [17] and personality [18, 19]. Additionally, previous literature reported that individuals with Internet addiction report a higher level of depression and suicide ideation [20, 21], higher level of social anxiety $[22,23]$, lower level of life satisfaction and problem-solving abilities [24], higher level of hyperactivity disorder [23], higher level of dysfunctional social behavior and loneliness [21], higher level of insomnia, snoring, apnea, teeth grinding and nightmares [25] and higher level of aggression[26]. Few studies have examined the effects of shame on social networking usage and Internet addiction [27-32].

Computer-based communication is gaining more popularity and prevalence over face-to-face communication. With this fact, shamed individuals may avoid from face-to-face communication much more than ever before by using computer-based communication (either overusing 
Internet or using SNS). As Young [33] stated, Internet addictions have a deep effect on one's quality of social life. As such, a deep understanding about Internet addiction and SNS as it relates to shame may provide functional results. In the studies in Turkey, SNS was investigated in context of motivational sources for SNS, usage of SNS, SNS types, spent time on SNS, friends on SNS, meeting SNS friends offline, etc. [34-41].

It is expected that this study will contribute to related Turkish literature as well. As such, we aimed to answer two questions in the current study. It was predicted that individuals with higher levels of shame would report higher levels of social network use and Internet addiction. For this reason, one of the aims is to examine if shame has any effect on Internet addiction and SNS usage. It was tested that the relation between shame and SNS usage is affected by Internet addiction. So, the second aim of the study is to understand mediator effect of Internet addiction in relation to shame and SNS usage. The model of the tested hypothesis is provided in Figure 1.

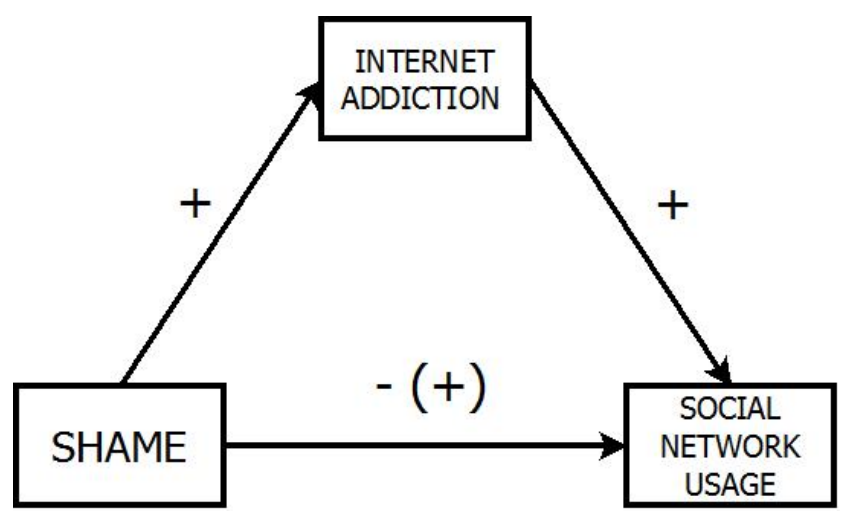

Figure 1. Model of the Mediational Role of Internet Addiction (Hypothetical Model)

\section{Research Design}

\subsection{Participants}

The study uses the purposive convenience sampling approach, through which the drawn samples are both easily accessible and willing to participate in the study, considering a representation of students from different faculties and departments at Muğla Sitkı Koçman University in Turkey. The research sample consisted of 488 voluntary students. The participants were selected among first-, second-, thirdand fourth-grade students. Of the participants, 265 (54\%) were female and $223(46 \%)$ were male, and their age range was between 18 and 26 years (Mean: 20.31). Before the data collection process, purposes of this study were explained to the participants. Researchers created a confident atmosphere for participants in their own classrooms, and questionnaires were completed anonymously by them.

\subsection{Procedure}

In order to determine the factors that contribute to the SNS usage, the regression analysis was applied to determine whether Internet addiction and shame predicted SNS usage. Furthermore, the simple mediation model was tested with "Process plugin" for SPSS. Process plugin, produced by Andrew F. Hayes [42], was explained in "Introduction to mediation, moderation, and process analysis: a regression-based approach." Process plugin works based on the assumption of Baron and Kenny's [43] mediation and moderation approach. Baron and Kenny [43] laid out several requirements that must be met to form a true mediation relationship: 1) Regress the dependent variable on the independent variable; 2) regress the mediator on the independent variable; 3 ) regress the dependent variable on both the mediator and independent variable. This step (step 3) involves demonstrating that when the mediator and the independent variable are used simultaneously to predict the dependent variable, the previously significant path between the independent and dependent variable (Step 1) is now greatly reduced, if not non-significant. If the relationship between dependent and independent variables is reducing, the mediator variable is called a "partial mediator"; if this relationship becomes non-significant, then the mediator variable is called a "full mediator." Process plugin executes all these steps simultaneously and presents all results in an output file. Thus, process plugin for SPSS was used to determine the mediating effect of Internet addiction on the relationship between shame and social media use. Additionally, the Pearson correlation coefficient was utilized to determine the relationships between variables among college students.

\subsection{Measures}

In the current study, shame subscale of the Trait Shame and Guilt Scale was administered to measure students' shame level. In addition, Internet Addiction Scale was used to measure Internet addiction levels of the participants. Social media usage levels were measured by the Social Media Use Scale. Detailed information about these measurements is given below.

The Trait Shame and Guilt Scale: Shame was measured by using Shame Subscale of The Trait Shame and Guilt Scale $[44,45]$ in our study. This subscale consists of 5 items with 5 -point Likert-type scale $(1=$ not feeling this way at all to $5=$ feeling this way very strongly). Higher score on subscale reflect a higher level of shame. Exploratory factor analysis for structural validity of the scale accounted for $63.52 \%$ total variance for Turkish adaption study. Shame subscale included five items and accounted for $23.59 \%$ of the variance. Results of confirmatory factor analysis indicated that the model was well-fit and Chi-Square value $\left(x^{2}=87, N=205, p=0.00, x^{2} / d f=2.62\right)$ which was calculated for the adaptation of the model was found to be significant. The goodness of fit index values of the model were 
RMSEA $=.06, \mathrm{GFI}=.92, \mathrm{CFI}=.94, \mathrm{RMR}=.044, \mathrm{SRMR}=.05$. In order to provide evidence of reliability, internal consistency coefficient was calculated for each subscale. The resulting Cronbach alpha for the Shame Subscale was .83 for our study.

Internet Addiction Scale: Internet addiction levels of the participants were measured by using Turkish version of Internet Addiction Scale [46, 47]. This scale consists of 19 items and it's a self-reported measurement and a 5-point Likert-type scale $(1=$ never $5=$ always $)$. Higher score indicates higher Internet addiction level. Exploratory factor analysis for structural validity of the scale accounted for $68.09 \%$ total variance for Turkish adaption study. Results of confirmatory factor analysis indicated that the model was well-fit and Chi-Square value $\left(\mathrm{x}^{2}=580.17, \mathrm{~N}=486, \mathrm{p}=0.01\right)$ which was calculated for the adaptation of the model was found to be significant. The goodness of fit index values of the model were RMSEA $=.079$, SRMR $=.045 \mathrm{NNFI}=.96$, $\mathrm{CFI}=.97, \mathrm{IFI}=0.95, \mathrm{GFI}=.90$ and $\mathrm{AGFI}=.85$. The Cronbach alpha internal consistency coefficient of our study was .86 .

Social Media Use Scale: Social media using level was measured by using Turkish version of Social Media Use Integration Scale [48, 49]. This scale has 10 items and it's a self-reported measurement on a 6-point Likert-type scale ( $1=$ totally disagree to $6=$ totally agree). Higher score indicate higher social media use. Results of confirmatory factor analysis indicated that the model was well-fit and Chi-Square value $\left(\mathrm{x}^{2}=65.59, \mathrm{~N}=247, \mathrm{sd}=32, \mathrm{p}=0.000\right)$ which was calculated for the adaptation of the model was found to be significant. The goodness of fit index values of the model were RMSEA $=.065, \mathrm{GFI}=.95, \mathrm{AGFI}=.91$, $\mathrm{CFI}=.97, \mathrm{NNFI}=.96, \mathrm{RFI}=.92$ and $\mathrm{IFI}=.097$. The Cronbach alpha internal consistency coefficient of our study was .87 .

\section{Results}

\subsection{Descriptive Data and Inter-correlations}

Descriptive statistics for all variables are presented below in Table 1. Means and correlation coefficients related to shame, Internet addiction and social media use are shown in Table 1.

Table 1. Descriptive findings and correlation matrix for variables used in analysis

\begin{tabular}{|c|c|c|c|c|c|}
\hline Variables & Mean & Sd & 1 & 2 & 3 \\
\hline 1-Shame & 10.55 & 5.01 & 1 & & \\
\hline 2-Internet Addiction & 37.51 & 14.62 & $.32^{*}$ & 1 & \\
\hline 3-SNS Usage & 24.76 & 10.26 & $.18^{*}$ & $.53 *$ & 1 \\
\hline$* \mathrm{p}<.01, \mathrm{n}=488$ & & & & & \\
\hline
\end{tabular}

Table 1 presents correlations between pairs of variables of the model. Analyses showed that there is a positive and significant relationship between all variables. As can be seen, there is a positive and significant relationship between shame and Internet addiction $(\mathrm{r}=.32)$. There is also a positive and significant relationship between SNS usage and shame $(\mathrm{r}=.18)$ and also between SNS usage and Internet addiction (.53).

\subsection{Mediating Analyses of Shame, Internet Addiction and Social Media Use}

By the means of mediation analyses, simple regression analysis applied to the data determined whether shame predicted social network usage or not. Results of a simple regression analysis for shame and SNS usage are shown below in Table 2.

Table 2. Regression coefficients, standard errors and significance tests for the regression Model on SNS usage

\begin{tabular}{|c|c|c|c|c|c|c|}
\hline Predictor & Coeff. & SE & P & F & $\mathrm{R}$ & $\mathrm{R}^{2}$ \\
\cline { 1 - 4 } Constant & 20.88 & 1.07 & $<.001$ & \multirow{2}{*}{16.24} & .18 & .10 \\
\cline { 1 - 5 } Shame & .37 & .09 & $<.001$ & & & \\
\hline
\end{tabular}

As can be seen in Table 2, regression analysis showed that shame significantly and positively predicted SNS usage (Coeff. $=.37,95 \%$ CI: .19-.55; $\mathrm{p}<.001)$. The result of mediating analysis is shown in Table 3 and Figure 2 below.

Table 3. Mediational model coefficients

\begin{tabular}{|c|c|c|c|c|c|c|c|c|}
\hline \multirow{3}{*}{ Predictions } & \multicolumn{8}{|c|}{ Consequent } \\
\hline & \multicolumn{5}{|c|}{ Internet Addiction } & \multicolumn{3}{|c|}{ SNS Usage } \\
\hline & & Coeff. & SE & $\mathrm{p}$ & & Coeff. & SE & $\mathrm{p}$ \\
\hline Shame & $\alpha_{\mathrm{i}}$ & .93 & .12 & .000 & $\mathrm{c}^{1}$ & .02 & .08 & .7578 \\
\hline $\begin{array}{c}\text { Internet } \\
\text { Addiction }\end{array}$ & & - & - & - & $\mathrm{b}$ & .37 & .03 & .000 \\
\hline \multirow[t]{3}{*}{ Constant } & $\mathrm{i}_{1}$ & 27.67 & .1 .46 & .000 & $\dot{\mathrm{I}}_{2}$ & 13.70 & 1.64 & .000 \\
\hline & \multicolumn{5}{|c|}{$\mathrm{R}=32, \mathrm{R}^{2}=.10$} & \multicolumn{3}{|c|}{$\mathrm{R}=.53, \mathrm{R}^{2}=.28$} \\
\hline & \multicolumn{5}{|c|}{$F(1,486)=55.36, p=.000$} & \multicolumn{3}{|c|}{$\mathrm{F}(2,485)=93.32, \mathrm{p}=.000$} \\
\hline
\end{tabular}




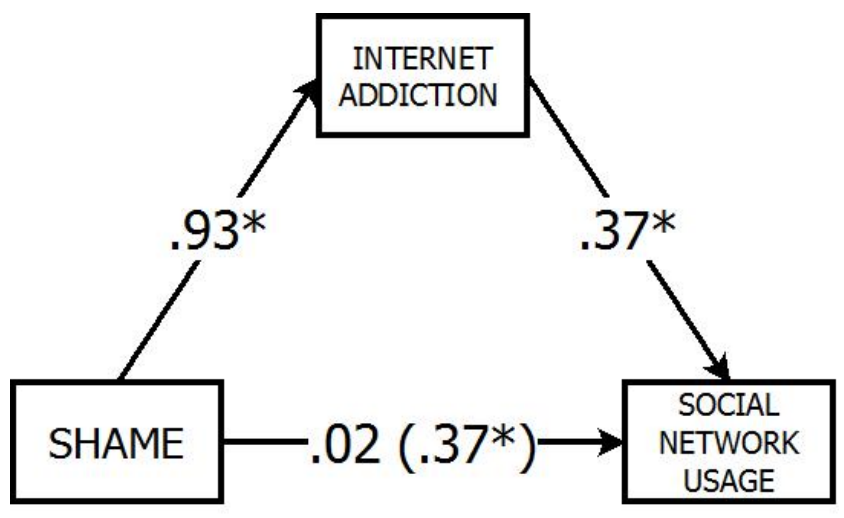

${ }^{*} p<.001,(z=6.42, p<.001)$

Figure 2. Model of the Mediational Role of Internet Addiction (Final Model)

As can be seen in Figure 2 and Table 3, the result of the mediation analysis showed that shame predicted Internet addiction (Coeff. $=.93,95 \% \mathrm{CI}$ : .19-.55; $\mathrm{p}<.001$ ); however, on the contrary, it did not predict SNS usage (Coeff. $=.02$, 95\% CI: -.13- .19; $\mathrm{p}<.01)$ in the mediation analysis. Internet addiction significantly predicted SNS usage (Coeff. $=.37$, 95\% CI: .31-.42; $\mathrm{p}<.01)$, and also decreased the effect of shame on SNS usage (from .37 to .02). Two different regression coefficients are revealed: the first one concerns the predicting effect of shame on SNS usage (Coeff. $=.37$, $\mathrm{p}<.001$ ); the second one concerns the predicting effect of shame on SNS usage when Internet addiction enters into analysis as a mediating variable (Coeff.=.02, $\mathrm{p}>.001$ ). According to a Sobel test, there is a significant difference between the mentioned coefficients above $(z=6.42, p<.001)$. Consequently, the results demonstrate that Internet addiction is a full mediator on the relationship between shame and SNS usage.

\section{Discussion}

In the current study, the association between shame, Internet addiction and SNS usage was examined. One of the findings suggests that shame predicts Internet addiction. Although few studies have examined the effects of shame on Internet addiction, the current result is consistent with previous studies. For example, Crapora, Messina, Severino, Fasciano, Cannella, Cacioppo and Baiocco [29] found shame as a predictor of Internet addiction. According to Chak and Leung [28], the higher the tendency of one being addicted to the Internet, the shyer the person is inclined to be. Huan, Ang, Chong and Chye [30] pointed out the mediating effect of loneliness on the relation between shyness and Internet addiction. The result is not surprising. Being ashamed may manifest itself in some behaviors such as avoidance of socialization and a preference to being alone. However, Internet usage has no social risk related to the reality of contact with other people. Therefore, this reality may lead ashamed individuals toward Internet overuse.

One of the findings of this study is that Internet addiction is an important predictor for SNS usage. This finding supports previous studies that found that Internet addiction is associated with SNS usage [50-52]. Kuss and Griffiths [53] reported in their study that egocentric construction of SNS usage may attract individuals to using Internet excessively. According to the researchers, this may lead to positive experiences that can potentially drive the development of Internet addiction. Actually, it is very hard to separate Internet addiction from SNS usage, because SNS usage is an indispensable part of Internet usage.

When participants' SNS usage was evaluated in relation to shame, another finding of this study is that greater SNS usage is associated with feeling even more shame. This finding supports other studies reporting that shame plays an important role in social networking [5, 7, 10, 14]. Additionally, Ryan and Xenos [32] report that frequency of Facebook usage varies as a result of certain user characteristics, like shyness. Baker and Oswald's [27] study results indicated shy individuals have a tendency to relate more between Facebook use and friendship quality when compared to their less shy peers.

Orr et al. [31] found that shy individuals tend to spend much more time on Facebook, and that being shyer can equate to having more friends on Facebook. As Shaw et al. [5] stated, social networking platforms present a secure area in social contexts, especially for individuals feeling shame. For individuals experiencing shame, social networking is a channel, full of advantages, to communicate with many people without any face-to-face communication. For these individuals, contact with other people by social networking and socializing without anxiety is a perfect match.

One of the findings showed that shame predicted SNS usage, but when Internet addiction steps into this association, the effect of shame decreases on SNS usage. More clearly, shame did not predict SNS usage when Internet addiction was a matter of the model. Therefore, Internet addiction is a mediating variable between shame and SNS usage. This result could be explained by the nature of Internet addiction. Internet addiction involves losing control and impairment of function [2]. With the view of having lost control, with or without shame, individuals want to use social networking. Because they are not controlling themselves, they most probably want to use Internet more and more, and the most well-known way of using Internet is through social networking [54]. With this impaired function, Internet-addicted individuals impair their daily life functions in their social life. Considering this fact, they may not give importance to the idea of being sociable or ashamed as before. Thus, Internet-addicted individuals, ashamed or not, lose the sense of shame's importance while they are using social networking.

In conclusion, the Internet addiction problem among young adults may become a public health problem, and it can have social repercussions on the user, including diminished social interactions, lessened social abilities and other behavioral problems in the public forum. As a fundamental result of this study, promoting people's social abilities to cope with shame can decrease the Internet addiction problem and dysfunctional SNS usage. 
This study has several limitations. First, although we applied the sample validated and reliable scales, the survey method has its own limitations because it was based on self-report. Second, our results are not generalizable to the entire population of college students because this study is limited to some faculties of a Turkish university. However, since a primary goal is to test the theoretical relationships between the variables, our sample has enough statistical power to be effective in meeting this goal. Third, this study was conducted with a community sample.

However, Internet addiction is a clinical problem and warrants additional study. For future research, replication of this study in a clinical sample could present important implications. Additionally, this study may be conducted in different populations (for example, among different age ranges), which could present important implications. This can also help researchers to understand developmental differences within different life stages by means of the Internet addiction's mediator effect's link to SNS usage and shame. What is more, smart phone use makes it much easier to reach the Internet and social networks in daily life presenting a new avenue for addiction and, thus, speculation. As such, a new model can be tested by putting a smart phone-use variable into the equation of Internet use, SNS and shame.

As deterrents to this issue, school counselors might consider conducting groups to help young adults cope with feeling shy in social situations. Also, more social activities and social works could be added to the school curriculum. This would begin to help young adults to cope with their Internet addiction risks or problems and overuse of social network. Furthermore, dysfunctional Internet use and its consequences on one's social development may be presented to adolescents as a fact within appropriate activities in schools.

\section{REFERENCES}

[1] L. R. Atkinson, C. R. Atkinson, E. E. Smith et al., Psikolojiye giriş (Introduction to Psychology), Ankara: Arkadaş Yayınları, 2002.

[2] K. S. Young, Caught in the Net: How to recognize the signs of internet addiction and a winning strategy for recovery, New York: Wiley, 1998.

[3] K. S. Young, "Internet addiction," American Behavioral Science, vol. 48, no. 402-415, 2004.

[4] G. Kaufman, The psychology of shame, Springer Publishing Company: New York, 1996.

[5] A. M. Shaw, K. R. Timpano, T. B. Tran et al., "Correlates of facebook usage patterns: the relationship between passive facebook use, social anxiety symptoms, and brooding," Computers in Human Behavior, vol. 48, pp. 575-580, 2015.

[6] J. Bollen, B. Gonçalves, G. Ruan et al., "Happiness is assortative in online social networks," Artificial Life, vol. 17, no. 3, pp. 237-251, 2011/07/01, 2011.

[7] A. C. Weidman, K. C. Fernandez, C. A. Levinson et al., "Compensatory internet use among individuals higher in social anxiety and its implications for well-being,"
Personality and Individual Differences, vol. 53, no. 3, pp. 191-195, 2012.

[8] O. Kwon, and Y. Wen, "An empirical study of the factors affecting social network service use," Computers in Human Behavior, vol. 26, no. 2, pp. 254-263, 2010.

[9] U. Doğan, and T. S. Çolak, "Self-concealment, social network sites usage, social appearance anxiety, loneliness of high school students: A Model Testing," Journal of Education and Training Studies, vol. 4, no. 6, pp. 176-183, 2016.

[10] P. Sheldon, "The relationship between unwillingness-to-communicate and students' Facebook use," Journal of Media Psychology, vol. 20, no. 2, pp. 67-75, 2008.

[11] A. L. Forest, and J. V. Wood, "When social networking is not working individuals with low self-esteem recognize but do not reap the benefits of self-disclosure on facebook," Psychological Science, vol. 23, no. 3, pp. 295-302, 2012.

[12] M. Kalpidou, D. Costin, and J. Morris, "The relationship between Facebook and the well-being of undergraduate college students," Cyberpsychology, Behavior, Social and Networking, vol. 14, no. 4, pp. 183-9, Apr, 2011.

[13] U. Doğan, "Effects of social network use on happiness, psychological well-being, and life satisfaction of high school students: Case of facebook and twitter," Education and Science, vol. 41, no. 183, pp. 217-231, 2016.

[14] J. R. Rae, and S. D. Lonborg, "Do motivations for using Facebook moderate the association between Facebook use and psychological well-being?," Frontiers in Psychology, vol. 6, Jun, 2015.

[15] S. A. Satıc1, and R. Uysal, "Well-being and problematic Facebook use," Computers in Human Behavior, vol. 49, pp. 185-190, 8//, 2015.

[16] E. C. Tandoc Jr, P. Ferrucci, and M. Duffy, "Facebook use, envy, and depression among college students: Is facebooking depressing?," Computers in Human Behavior, vol. 43, pp. 139-146, 2//, 2015.

[17] A. Moreau, S. Laconi, M. Delfour et al., "Psychopathological profiles of adolescent and young adult problematic Facebook users," Computers in Human Behavior, vol. 44, pp. 64-69, 3//, 2015.

[18] Y.-C. J. Wu, W.-H. Chang, and C.-H. Yuan, "Do Facebook profile pictures reflect user's personality?," Computers in Human Behavior, 2014.

[19] X. Zhu, S. E. Woo, C. Porter et al., "Pathways to happiness: From personality to social networks and perceived support," Social Networks, vol. 35, no. 3, pp. 382-393, 7//, 2013.

[20] K. Kim, E. Ryu, M. Y. Chon et al., "Internet addiction in Korean adolescents and its relation to depression and suicidal ideation: a questionnaire survey," International Journal of Nursing Studies, vol. 43, no. 2, pp. 185-192, 2006.

[21] L. S.-M. Whang, S. Lee, and G. Chang, 'Internet over-users' psychological profiles: A behavior sampling analysis on internet addiction," CyberPsychology \& Behavior, vol. 6, no. 2, pp. 143-150, 2003/04/01, 2003.

[22] M. H. Selfhout, S. J. Branje, M. Delsing et al., "Different types of internet use, depression, and social anxiety: The role of perceived friendship quality," Journal of Adolescence, vol. 32, no. 4, pp. 819-833, 2009.

[23] J. Y. Yen, C. H. Ko, C. F. Yen et al., "The comorbid psychiatric symptoms of Internet addiction: attention deficit and hyperactivity disorder (ADHD), depression, social phobia, and hostility," Journal of Adolescent Health, vol. 41, no. 1, pp. 93-98, 2007. 
[24] Z. Kabasakal, "Life satisfaction and family functionas as predictors of problematic Internet use in university students," Computers in Human Behavior, vol. 53, pp. 294-304, 2015.

[25] K. Choi, H. Son, M. Park et al., "Internet overuse and excessive daytime sleepiness in adolescents," Psychiatry and Clinical Neurosciences, vol. 63, no. 4, pp. 455-462, 2009.

[26] K. Kim, "Association between Internet overuse and aggression in Korean adolescents," Pediatrics International, vol. 55, no. 6, pp. 703-709, 2013.

[27] L. R. Baker, and D. L. Oswald, "Shyness and online social networking services.," Journal of Social and Personal Relationships, vol. 27, no. 7, pp. 873-889, 2010.

[28] K. Chak, and L. Leung, "Shyness and locus of control as predictors of internet addiction and internet use," CyberPsychology \& Behavior., vol. 7, no. 5, pp. 559-570, 2004.

[29] G. Craparo, R. Messina, S. Severino et al., "The relationships between self-efficacy, internet addiction and shame," Indian Journal of Psychological Medicine, vol. 36, no. 3, pp. 304-307, 2014

[30] V. S. Huan, R. P. Ang, W. H. Chong et al., "The impact of shyness on problematic internet use: The role of loneliness," The Journal of psychology, vol. 148, no. 6, pp. 699-715, 2014.

[31] E. S. Orr, M. Sisic, C. Ross et al., "The influence of shyness on the use of Facebook in an undergraduate sample," CyberPsychology \& Behavior, vol. 12, no. 3, pp. 337-340, 2009.

[32] T. Ryan, and S. Xenos, "Who uses Facebook? An investigation into the relationship between the Big Five, shyness, narcissism, loneliness, and Facebook usage," Computers in Human Behavior, vol. 27, no. 5, pp. 1658-1664, 9//, 2011.

[33] K. S. Young, "Internet addiction: The emergence of a new clinical disorder," CyberPsychology \& Behavior, vol. 1, no. 3, pp. 237-244, 1998.

[34] K. Bilen, O. Ercan, and T. Gülme, "Sosyal ağların kullanım amac1 ve benimseme süreci; Kahramanmaraş Sütçü İmam üniversitesi örneği (Intended uses and adoption process of social networks; Kahramanmaras Sütçü İmam university example)," Journal of Research in Education and Teaching, vol. 3, no. 1, pp. 115-123, 2014.

[35] F. Eren, İ. Çelik, and A. O. Aktürk, "Ortaokul öğrencilerinin facebook algis1: Bir metafor analizi (Secondary school students' perceptions of Facebook: A metaphor analysis)," Kastamonu Eğitim Dergisi, vol. 22, no. 2, pp. 635-648, 2014.

[36] A. İşman, and E. Albayrak, "Ağlardan facebook'un eğitime yönelik etkililiği (Effectiveness of facebook as a social network in education)," Trakya University Journal of Education, vol. 4, no. 1, pp. 129-138, 2014.

[37] A. İşman, and N. B. Hamutoğlu, "Sosyal ağlarin eğitim-öğretim sürecinde kullanılması ile ilgili karma öğrenme öğrencilerinin görüşleri: Sakarya üniversitesi örneği (Blended student's views about using social networks in education period: A case study in Sakarya university)," International Journal of New Trends in Arts, Sports \& Science Education, vol. 2, no. 3, pp. 61-67, 2013.

[38] K. Kobak, and S. Biçer, "Facebook sosyal paylaşım sitesinin kullanım nedenleri (Usage foctors of Facebook social share site)." pp. 567-571.

[39] M. Öztürk, and Ö. E. Akgün, "Üniversite öğrencilerinin sosyal paylaşım sitelerini kullanma amaçları ve bu sitelerin eğitimlerinde kullanılması ile ilgili görüşleri (University students' purposes in using social networking sites, and their opinions on using these sites in education)," Sakarya University Journal of Education, vol. 2, no. 3, pp. 49-67, 2012.

[40] H. Şahin Baltacı, F. İşleyen, and S. Özdemir, "Eğitim fakültesi öğrencilerinin romantik ilişki durumları ve sosyal ağ kullanımlarına göre etkileşim kaygısı ve sosyal destek algilarının incelenmesi (The investigation of interaction anxiety and social support perceptions of the faculty of education students according to the romantic relationship status and social network use)," Mersin University Journal of the Faculty of Education, vol. 8, no. 2, pp. 25-36, 2012.

[41] G. Şener, "A study of use facebook in Turkey."

[42] A. F. Hayes, Introduction to mediation, moderation, and conditional process analysis: A regression-based approach, New York: Guilford Press, 2013.

[43] R. M. Baron, and D. A. Kenny, "The moderator-mediator variable distinction in social psychological research: Conceptual, strategic, and statistical considerations," Journal of Personality and Social Psychology, vol. 51, no. 6, pp. 1173-1182, 1986.

[44] A. Bugay, and A. Demir, "Psychometric properties of the Turkish version of trait shame and guilt scale," Eurasian Journal of Educational Research, vol. 45, pp. 17-30, 2011.

[45] N. Rohleder, E. Chen, J. M. Wolf et al., "The psychobiology of trait shame in young women: extending the social self-preservation theory," Health Psychology, vol. 27, no. 5, pp. 523-532, 2008.

[46] A. Hahn, and M. Jerusalem, "Internetsucht — reliabilität und validität in der online-forschung," In Online-Marktforsc, A. Theobald, M. Dreyer and T. Starsetzki, eds., pp. 213-233, Weisbaden: Gabler Verlag, 2001.

[47] C. Şahin, and Ö. Korkmaz, "İnternet bağımlılığı ölçeğinin Türkçe'ye uyarlanması (Adaptation of internet addiction scale to Turkish)," Ahmet Kelesoglu Education Faculty (AKEF) Journal, vol. 32, pp. 101-115, 2011.

[48] A. Akın, F. Usta, E. Uğur et al., "The validity and reliability of the Turkish version of the social media use scale," in 18. National Congress of psychology, 9-12 April, Bursa, Turkey, 2014.

[49] M. A. Jenkins-Guarnieri, S. L. Wright, and B. Johnson, "Development and Validation of a Social Media Use Integration Scale," Psychology of Popular Media Culture, vol. 2, no. 1, pp. 38-50, 2013.

[50] R. Kittinger, C. J. Correia, and J. G. Irons, "Relationship between Facebook use and problematic Internet use among college students," Cyberpsychology, Behavior, and Social Networking, vol. 15, no. 6, pp. 324-327, 2012.

[51] K. W. Müller, M. Dreier, M. E. Beutel et al., "A hidden type of internet addiction? Intense and addictive use of social networking sites in adolescents," Computers in Human Behavior, vol. 55, no. 172-177, 2016.

[52] C. C. Tsai, and C. C. Lin, "Taiwanese adolescents' perceptions and attitudes regarding the Internet: Exploring gender differences", Adolescence, vol. 156, no. 725-734, 2004.

[53] D. J. Kuss, A. J. van Rooij, G. W. Shorter et al., "Internet addiction in adolescents: Prevalence and risk factors," Computers in Human Behavior, vol. 29, no. 5, pp. 1987-1996, 9//, 2013.

[54] J. V. Dijck, The culture of connectivity: A critical history of social media, Oxford: OUP Premium, 2013. 